\title{
Plastic Surgery Update on the Mesenchymal Stem-Cell Derived Extracellular Vesicles towards Cell-Free Therapeutic Applications
}

\author{
Gordon H. Sasaki ${ }^{1,2}$ \\ ${ }^{1}$ Sasaki Advanced Aesthetic Medical Center, Pasadena, USA \\ ${ }^{2}$ Loma Linda University Medical Center, Loma Linda, USA \\ Email: ghsasakimd@drsasaki.com
}

How to cite this paper: Sasaki, G.H. (2021) Plastic Surgery Update on the Mesenchymal Stem-Cell Derived Extracellular Vesicles towards Cell-Free Therapeutic Applications. Open Access Library Journal, 8: e7393. https://doi.org/10.4236/oalib.1107393

\section{Received: April 7, 2021}

Accepted: September 25, 2021

Published: September 28, 2021

Copyright $\odot 2021$ by author(s) and Open Access Library Inc.

This work is licensed under the Creative Commons Attribution International License (CC BY 4.0).

http://creativecommons.org/licenses/by/4.0/

\section{Open Access}

\begin{abstract}
In the biogenesis of extracellular vesicles (EVs), exosomes and other lipid-lined vesicles are released upon fusion of multivesicular bodies with the cell membrane of stem cells. EVs contain a diverse number of growth factors, cytokines and bioactive molecules of proteins, lipids, microRNA, and mRNA that mediate cell-cell communications for homeostasis, immune signaling, angiogenesis, anti-inflammation, senescence, proliferation, and differentiation. To further explore its potential usages, plastic surgeons are beginning to show an increased interest in this novel cell-free therapy to partially explain the paracrine effects of cell-based therapies on cell repair, tissue engineering, and aesthetic rejuvenation. The burgeoning preclinical and clinical experience appears to be promising, but current in vitro studies, translational research, and IRB-registered investigations emphasize the need to clarify product identification/purity, attributed biologic functions, standardized protocols, and applications to advance basic science findings and provide beneficial safe clinical outcomes. Since the specialty of Plastic Surgery is committed to advancing evidence-based stem cell studies in compliance with FDA regulations, an updated review of EVs is timely to provide insights to achieve these goals.
\end{abstract}

\section{Subject Areas \\ Surgery \& Surgical Specialties}

\section{Keywords}

Regenerative Medicine, Extracellular Vesicles, Mesenchymal Stem Cells 


\section{Introduction}

The goals of Plastic Surgery and Regenerative Medicine are often intertwined because of similar aims to functionally restore injured, malfunctioning and absent tissue by cell, tissue, organ-based therapies [1]-[6] or by tissue engineering combining cells with natural or synthetic scaffolds [7] [8] [9] [10] [11]. For these therapies to succeed, however, the presence of intercellular communications becomes indispensable to direct tissue repair, growth and development and is believed to be mediated through either direct cell-cell contact (juxtacrine signaling) and/or by secreting soluble molecules, such as hormones, growth factors, cytokines, chemokines and neurotransmitters with specific membrane receptors (secretome signaling) [12]. These soluble factors can act on the cell itself (autocrine) or have an impact on both adjacent (paracrine) and distant cells (endocrine).

From the inception of our specialty, plastic surgeons have recognized the value of autogenous tissue as a practical replacement for point-of-care correction of reconstructive and aesthetic purposes. Subsequent investigators later determined that mesenchymal stem cells (MSCs) are self-renewing, multipotent progenitors involved in multilineage differentiation, tissue repair, anti-inflammation, immunosuppression and neuroprotection [13]-[18]. Although the underlying mechanisms that regulate these biological functions are not precisely known, earlier investigations favored the concept that MSCs homed to injured tissue and replenished damaged cells or apoptotic cell populations along their particular cell differentiation pathways. Current studies, however, give more weight to the importance of cell signaling molecules, released by MSCs, than cell replication, to account for tissue recovery emphasizing their paracrine functions of cellular repair by angiogenesis and suppression of inflammation by the host-derived cells [19] [20] [21] [22] [23]. In plastic surgery, these adult stem cells are isolated primarily from adipose tissues and bone marrow because of their in vivo expansion capability and ethical acceptability [24] [25] [26]. However, cell therapies have been limited because of immunologic incompatibilities that prevent allogeneic usages for clinical potential. Furthermore, the current regulatory environment restricts the use of cell therapies because of limited long-term controlled studies that demonstrate safety and efficiency issues associated with undesirable differentiation and de-differentiation, senescence-induced genetic instability and cell survival [27] [28] [29] [30] [31].

In the past three decades, a third mechanism by which mesenchymal stem cells act in a paracrine fashion has emerged that involves intercellular transfer of extracellular vesicles (EVs), also known as exosomes [32]. Although other subtypes of EVs have been identified, such as microvesicles (MVs), membrane particles, and apoptotic bodies, this chapter will focus mainly on the current knowledge on the composition, functions and isolation strategies of MSC-derived exosomes. As a cell-free alternative to stem-cell-based strategies, EVs may be adoptable to other tissue regenerative applications that may be unhampered 
from allogeneic constraints and still remain under the strict regulatory guidelines as a biologic product in the practice of plastic surgery.

\section{Literature Review}

Prokaryotic and eukaryotic cells have conserved an evolutionary remnant for cell-cell functional communications during physiological and pathological processes through the secretion of EVs. Initially, the release of EVs was believed to represent a waste disposal mechanism for cells to eliminate unwanted molecular material in its extra or intra-cellular environment. Although Chargaff and West (1946) [33] observed platelet-derived particles, that was later referred to as "platelet dusts" by Wolf (1967) [34], Pan and Johnstone (1983) [35] clearly described them as membrane-contained vesicles of endosomal origin secreted from sheep reticulocytes. In 1987 Johnstone [36] coined the term "exosomes" to describe the vesicle formation and release from the reticulocyte's cell membrane. Twenty years later, Viladi [37] discovered that EVs shuttled mRNA and microRNA strands of genetic material between cells as mediators of normal and pathological cell-to-cell communications.

Each human cell type is capable of secreting different subspecies of EVs that possess specific physiologic properties, content, and functions for their own waste management and recycling of membrane proteins and lipids, as well as for targeting adjacent recipient cells to influence their immune modulations, senescence profile, angiogenesis, and cellular proliferation and differentiation [38] [39] [40] [41]. Although EVs have been isolated in all body fluids, including blood, urine, saliva, breast milk, pleural effusions, bronchioalveolar lavage, synovial fluid, amniotic fluid, ascites, cerebrospinal fluid, bile and semen [42], a major ongoing challenge remains the establishment of standardized methods that can distinguish amongst the different isolated subtypes on the basis of their size, morphology, density, composition, main protein markers, and subcellular origin (plasma membrane vs intracellular compartment). In the past, vesicular nomenclature was primarily based on the tissue of origin. More recently, the EV community has shifted towards a terminology based on mechanism of generation of these vesicles. As a consequence of their cell of origin, the molecular compositions of EVs are diverse containing a variety of intracellular cytosolic proteins [43] (endosome-associated RAB GTPase, SNAREs, Annexins, and flotillin) and cytoskeletal proteins (actins, cofilin, tubulin), extracellular membrane adhesion proteins [44] [45] (adhesion domains of integrins and tetraspanins $\left[\mathrm{CD}^{63}, \mathrm{CD}^{81}, \mathrm{CD}^{82}, \mathrm{CD}^{53}, \mathrm{CD}^{37}\right]$, lipids [46] (cholesterol, sphingomyelin, phosphotidylserine, and hexosylceramides), RNA [47] [48] (mRNA, microRNA), and DNA fragments [49]. Although the above-mentioned molecular compositions of EVs have been reported, none of them is described as a distinct marker that identifies subsets of EVs. The database ExoCarta (http://www.exocarta.org) and Vesiclepedia continue to update and identify these novel components. Currently, there remains no consensus about the nomenclature or classification of 
cell-derived EVs. Members of the International Society of Extracellular Vesicles continue efforts to define equivalent and standardized protocols for isolation and characterization of EVs.

\section{Current Limitations of Isolation and Characterization of EVs}

The inter-related complexities of detection, recovery and characterization of EVs have been hampered by the complex nature of biological fluids, heterogenous and overlapping vesicular sizes, densities and shapes, which are summarized in Table 1. The use of variable g-forces and other sophisticated separation techniques during differential centrifugation processes [50] [51] [52] also contribute to dilution, fragmentation, fusion, and contamination of pellets with cellular components. That being said, centrifugal and ultra-centrifugal forces of $200-1500 \mathrm{~g}$ are useful to segregate discarded cells and cellular debris, while greater forces of $10,000-20,000 \mathrm{~g}$ isolate vesicles larger than $100 \mathrm{~nm}$, and 100,000 - 200,000 g collect vesicles smaller than $100 \mathrm{~nm}$. Since 2011, efforts to develop new technologies [53] are being coordinated with the International Society for Extracellular Vesicles to unify the nomenclature and methodologies of EVs (www.journalofextracellularvesicles.net).

\subsection{Size and Morphology}

Although Transmission Electron Microscopy (TEM) [54] [55] has been the preferred technique for determining the size and morphology of EVs, the vacuum, fixation and dehydration processes create artifacts that can display appearances ranging from a cup-like to round configurations. Since most differential size determinations are based ideally on the number of vesicles per unit particle size and suspension volume, the associated variables of TEM or fluorescence microscopy, super-resolution microscopy, and nanoparticle tracking devices probably do not convey the natural sized population of EVs. However, quantitative analysis of multiple EVs in many samples underscore the heterogenous diameter measurements of exosomes [56] (30 - $150 \mathrm{~nm})$, microvesicles [57] [58] [59] (20 $1000 \mathrm{~nm})$, membrane particles [60] $(50-80 \mathrm{~nm}, 600 \mathrm{~nm})$, and apoptotic vesicles [61] (1000 - $5000 \mathrm{~nm})$.

\subsection{Density}

One of the most defining characteristics that distinguish different extracellular vesicles is their ability to equilibrate at different levels by sucrose density gradient centrifugation [62]. Like all lipid vesicles, EVs equilibrate at densities ranging from 1.13 to $1.19 \mathrm{~g} / \mathrm{mL}$ from pooled fractional analyses [50] [54]. Although subtypes of EVs can be separated by buoyant velocity centrifugation in a sucrose gradient for varying lengths of time [63], density studies emphasize that EVs are heterogenous and, therefore, will require new technologies to distinguish their densities in both small and large vesicles. 
Table 1. Characteristics of different subtypes of extracellular vesicles.

\begin{tabular}{|c|c|c|c|}
\hline Features & Exosomes & Microvesicles & Apoptotic Bodies \\
\hline Diameter & $30-150 \mathrm{~nm}$ & $50-1000 \mathrm{~nm}$ & $1000-5000 \mathrm{~nm}$ \\
\hline Appearance & cup - shape & cup - round shapes & variable shapes \\
\hline Density in (Sucrose Gradient) & $1.13-1.19 \mathrm{~g} / \mathrm{mL}$ & $1.04-1.07 \mathrm{~g} / \mathrm{mL}$ & $1.16-1.28 \mathrm{~g} / \mathrm{mL}$ \\
\hline Sedimentation & $100,000 \mathrm{~g}$ & $10,000 \mathrm{~g}$ & $16,000 \mathrm{~g}$ \\
\hline Marker Proteins & tetraspanins, Alix, TSG101 & integrins, selectins, CD40 ligand & histones \\
\hline Origin & $\begin{array}{l}\text { Endosome budding into MVBs, fusion } \\
\text { of MVB with cell membrane }\end{array}$ & Outward budding of cell membrane & $\begin{array}{l}\text { Outward blebbing of apoptotic cell } \\
\text { membrane }\end{array}$ \\
\hline Composition & $\begin{array}{l}\text { Protein, lipids, coding RNA, } \\
\text { Noncoding RNA, DNA }\end{array}$ & $\begin{array}{l}\text { Protein, lipids, cell organelles, } \\
\text { coding RNA, noncoding RNA, } \\
\text { DNA }\end{array}$ & $\begin{array}{l}\text { Cell organelles, proteins, nuclear } \\
\text { fragments, coding RNA, noncoding } \\
\text { RNA, DNA }\end{array}$ \\
\hline
\end{tabular}

\subsection{Molecular Composition}

Most studies on the biochemical composition of EVs are based on protein, lipid and nucleic acid analysis of the vesicles' intracellular or extracellular membrane origins by a number of techniques such as differential ultracentrifugation, western blotting and mass spectroscopy of total populations or by fluorescent flow cytometry of single vesicles. Currently, the exact composition of each subtype has not been defined. The database ExoCarta [64] (http://www.exocarta.org) and the updated compendium Vesiclepeida [65] continue to catalogue proteins, lipids and RNA and purification procedures from different groups with equivalent and standardized EV isolation protocols.

\subsubsection{Proteins}

Proteomic investigations demonstrated that exosomes are composed of a specific subset of extracellular and cellular proteins of the cell type that secretes them but also composed of nonspecific intracellular proteins from endosomes, plasma membrane, and cytosol that are common to all cell types. Of interest, exosomes are usually lacking proteins found in their nucleus, mitochondria, endoplasmic reticulum and the Golgi apparatus suggesting that protein sources are selected from specific subcellular compartments and not obtained from other randomly available protein entities. Columbo et al. [66] have proposed a schematic representation of a canonical exosome depicting a vesicle enclosed by a bi-lipid layer that is populated with spatially specific intracellular domains of 1) lipid raft-bound fusion proteins of annexins, flotillins, RABs, and ARFs and 2) other intracellular domains of cytosolic histones, ribosomal proteins, and proteasomes, as well as extracellular domains of transmembrane-bound proteins of LSMPSs, and TfRs, and other adhesion molecules of tetraspanins and integrins. Although the protein content of exosomes has been extensively investigated, refinements of purification techniques are continuing to clarify their functional roles in each EV subgroup. 


\subsubsection{Lipids}

The characteristic composition of the bi-lipid layer around exosomes is made up of specific families of sphingomyelin, phosphatidylserine, cholesterol, and ceramide with lipid-raft domains of proteins that are distributed differently within EV subtypes [67] [68]. Lipids are not randomly included into EVs but, similar to other biomolecules, they are specifically sorted to provide structural rigidity to EVs [69] and possibly to be involved in their formation and release [70]. It remains unclear whether the makeup of portions of the bi-lipid layer of the cell's plasma membrane (PM) that contribute to the sorting complex remain the same throughout the transformative process of endosomes (IEs) to intraluminal vesicles (ILVs) housed within multi-vesicle bodies (MVBs). Studies show that exosomes differ from the secreting cells in terms of lipid composition suggesting the presence of sorting mechanisms for these specific lipid species into vesicles (see Biogenesis of Extracellular Vesicles Biogenesis, below). Further studies are required to elucidate the roles of lipids in the biogenesis and biological functions of EVs.

\subsubsection{Ribonucleic Acids (RNAs)}

Since the 2006-2007 discoveries of RNAs in murine-derived EVs [37] [71], subsequent studies found the presence of intact mRNA [72], mRNA fragments [73], long non-coding RNA [74], miRNA [48], piwi-interacting RNA [74], and fragments of tRNA [75]. Most studies reported absence or minor presence of ribosomal $18 \mathrm{~S}$ and $28 \mathrm{~S}$ in EVs [76]. Evidence suggest that certain populations of RNAs are loaded and enriched in specific subtypes of EVs and excluded in others by active sorting mechanisms [77] [78]. By horizontal transfer, loaded EVs were observed to release specific mRNAs that regulated gene expression in the parental cells [79], increased protein expression in other cells [71], triggered neoangiogenesis in endothelial cells [80], enhanced cell survival and repair tissue under stressful conditions [81] [82], and promote cell differentiation, proliferation, and immune regulation [82]. EV-mediated transfer of mRNAs from adipocytes has also been shown to stimulate lipid synthesis [83] and secreted into the blood circulation for other extracellular physiological roles [84] [85] [86] [87]. However, the precise individual RNA's contributions to regulate neighboring or distant cellular effects remain difficult to assess [74].

\subsubsection{Deoxyribonucleic Acids (DNAs)}

The presence of oncogenic DNAs, mitochondrial DNAs, single and double-stranded DNAs [88] [89] have been detected in EVs targeting fibroblasts [90] and in tumor cells [91]. Currently, the biological significance of DNA cargo in EVs is unknown.

\subsection{Biogenesis of Extracellular Vesicles}

Although microenvironmental factors such as hypoxia [92] and inflammation [93] have been proposed as initiators for MSCs to commence biogenesis and se- 
cretion of EVs, it is likely that both extracellular factors and intracellular demands play specific roles in the regulation and sorting of EVs for intracellular requirements and for cell-cell communications [94].

\subsubsection{Exosome Formation}

In the "classic endocytic pathway", the process begins in the parent cell membrane by the initiation of curvature-induction mechanism(s) that sort membrane constituents such as lectins [95], lipid-membrane protein rafts [96] [97], tetraspanin-enriched microdomains [98] [99] [100] for shaping, sizing, composing, and inward budding of the vesicle. Both the protein Endosomal Sorting Complex Required for Transport (ESCRT), located at the neck region of the emerging bud, and the clathrin-dependent or caveolae-dependent membrane pathways, are believed to play significant roles in the fission of the membrane's bud to form early endosomes.

Figure 1 shows the pathway of Extracellular Vesicles (EVs). Biogenesis, degradation and secretion of EVs generally follows the classic endolysosomal pathway that orchestrates Endocytosis, MultiVesicle Body (MVB) formation, Exosome (E) fusion and secretion, or autophagy induction and lysosomal cargo degradation and subsequent recycling, preserving cellular homeostasis. Alternatively, a second immediate pathway involves the release of Microvesicles (MV) directly from the plasma membrane often during cell stress. Different sorting pathways exist directing EVs predestined for either secretion or degradation. During apoptosis, membrane blebbing precedes the release of larger sized apoptotic vesicles. EVs deliver their cargo of proteins, lipids and RNAs by the interaction of transmembrane proteins on EVs with receptors on cell membranes through several pathways such as phagocytosis, fusion or endocytosis.

By the inward budding of the endosome membrane into their lumen, early endosomes developed into mature endosomes that accumulate intraluminal vesicles (ILVs) that are generally referred to as multivesicle bodies (MVBs). Although a number of investigations [101] [102] demonstrated the presence of ESCRT-independent mechanisms, other studies [103] [104] [105] found that ESCRT-dependent mechanisms were necessary for exosome biogenesis through the sorted binding of microdomains of ubiquitinilated proteins and lipid rafts for ILVs' sequestering of selective proteins, lipids and cytosols. Further investigations [106] [107] [108] suggest that incorporation of a given protein into ILVs may predestine the endosomal vesicles to follow one of two pathways. For example, subpopulations of MVBs may follow the classic intracellular pathway leading to either cargo degradation (lysosomal pathway for recycling) after ubiquitination of transmembrane proteins [109] or secretion indirectly as released exosomes when the MVB's membrane fuses with the cell's membrane [110]. A second pathway exists for other vesicular species that follow a direct pathway for their release from the cell membrane as microvesicles that are for the most part indistinguishable from exosomes in that they are capable to transfer functional genomic and proteomic content to recipient cells [71] [72] [109] [110] [111]. In 


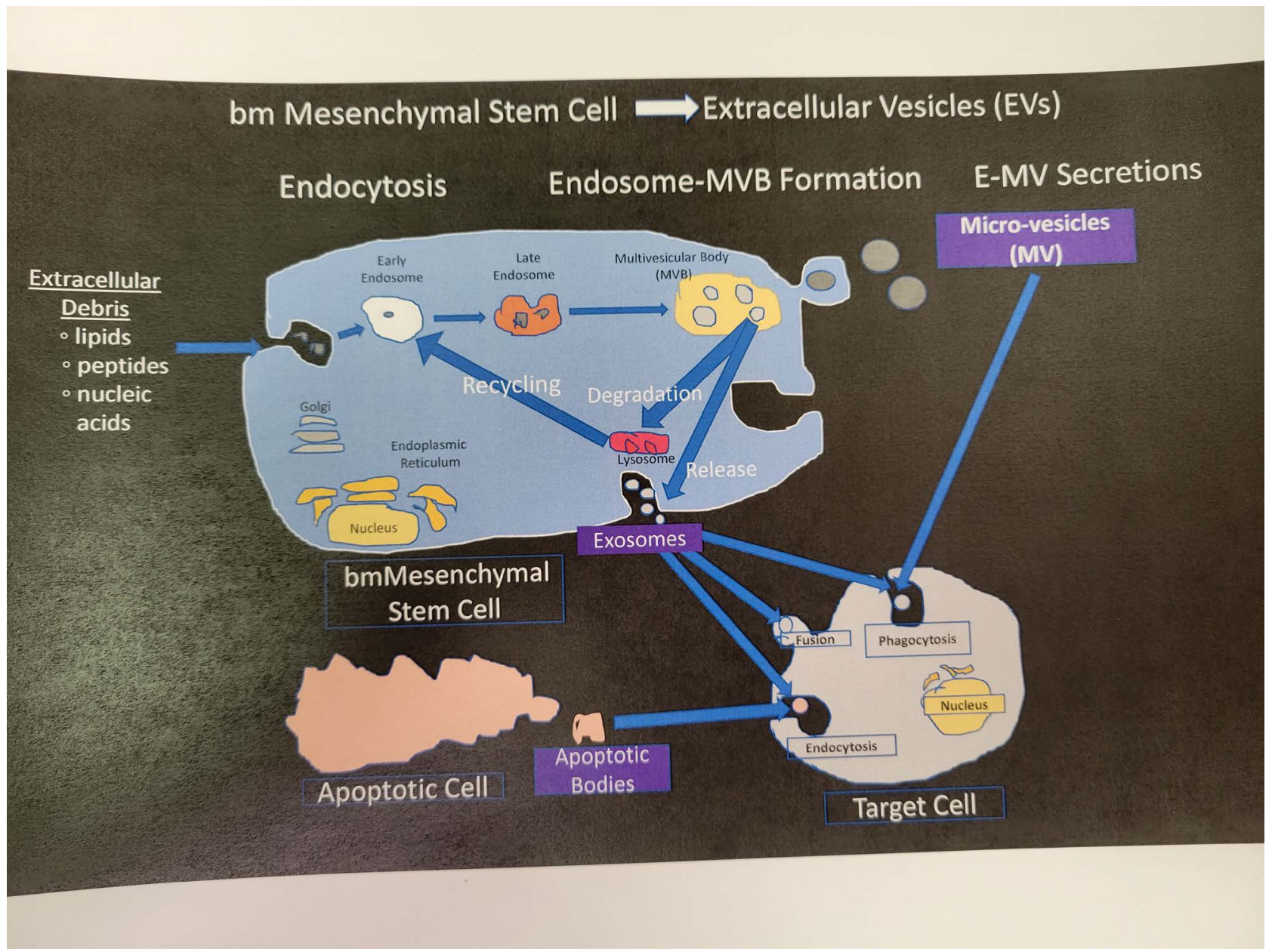

Figure 1. Extravesicle pathway.

most cells, different subpopulations of MVBs coexist with the majority destined to fuse with lysosomes to ensure degradation of their cargo, while others are designated for exocytosis as exosomes or microvesicles.

Apoptotic vesicles [59] [61] originate at the cell membrane in a process referred to as "membrane blebbing" as the cell undergoes death. The major differences between apoptotic vesicles and other cell-derived vesicles are their large sizes, variable shapes, and the presence of a specific histone marker [112]. Since platelets and apoptotic vesicles undergo similar blebbing process from their parent cell, they may be indistinguishable based on their similar ranges in size.

\subsubsection{EVs Secretion, Docking, and Endocytosis}

The processes involved with scission, release and docking of EVS from the cell membrane of the parent cell to the recipient cell's membrane surface are still being defined. These mechanisms are believed to involve the cytoskeleton (actin and micro-tubules), associated molecular motors (kinesins and myosins), molecular switches (small GTPases), the fusion apparatus (SNAREs and tethering factors) and the Rab proteins [113]. The RAB family of over 60 GTPases has garnered attention because they are believed to be essential regulators of intra- 
cellular vesicle transport between different compartments and also interactions between vesicle budding, mobility through cytoskeleton network, secretion release, and fusion on the acceptor cell membrane [114] [115].

The binding of EVs to the cell membrane is believed to involve the targeting of several specific ligand/receptor pairs on both EVs and the recipient's plasma membrane [116]. The first binding step of EVs to recipient cells might be sufficient to induce physiological responses in the recipient cells [117]. In other circumstances, EVs contents of proteins, lipids, and RNAs must be transferred through endocytotic mediated-pathways [118]. After internalization has occurred, the vesicles can be degraded and their contents recycled for usage or transferred as exosomes to recipient cells [119].

\subsubsection{EVs in Regenerative Medicine (Plastic Surgery)}

Since Owen [120] and Caplan [121] introduced respectively, the terms stromal stem cell or mesenchymal stem cells to the scientific literature over thirty years ago, MSCs have established themselves with in vitro and in vivo credentials with traits of self-renewal and multipotent differentiation. Under the criteria of the International Society of Cellular Therapy, MSCs are characterized by a combination of culture properties, phenotype markers, multi-lineage differentiation capacity and identification of tissue origin [122] [123]. MSCs exhibited intense paracrine activity by secreting a number of bioactive molecules (growth factors, cytokines) directly or releasing others moieties via the intracellular EVs pathways with trophic [124] [125], angiogenetic [126], immunomodulatory [127] and immunosuppressive [128] capacities to reduce apoptosis, inflammation, fibrosis, and promote angiogenesis and proliferation. In fact, most of these secreted bioactive molecules consisted of soluble factors, exosomes and microvesicles [129]. As of 2012, open hMSCs clinical trials registered at clinicaltrials.gov include the treatment of graft-versus-host diseases, autoimmune disorders, bone and cartilage repair, cardiac, neurological and renal diseases [130] [131] [132] [133] [134].

For over a century, adipose tissue has been the preferred autologous tissue replacement for many reconstructive and aesthetic procedures in plastic surgery [135]. Besides its attributes as an autogenous graft material, adipose tissue is recognized as a more attractive supplier of adult adipose-MSCs [136]. Within the past two decades, two separate autologous adipose-derived stem cell therapies emerged as promising methods to improve fat grafting. Of the two, the combination of adipose tissue either with adipose stem cells (ASCs), derived enzymatically from stromal vascular fraction (SVF), has been the most controversial strategy because of regulatory concerns and varied results [137]. Surgeons reported both encouraging [138] [139] [140] [141] [142] and equivocal [143] [144] outcomes with SFV cell-assisted lipo-transfer. A second less contentious clinical strategy is represented by combining adipose tissue with either mechanically-derived adipose mesenchymal stem cells [145]-[150] or with platelet-rich plasma (PRP) [142] [151] [152] [153] [154]. However, a critical and comprehen- 
sive reading of the positive published outcomes with either mechanically-derived adipose-stem cells or platelet-enriched plasma leads to the conclusion that designed randomized controlled trials are needed to demonstrate unambiguous long-term results. Stem-cell-based therapies are based on autologous harvesting and transplantation. As examples of cellular therapy, adipose-stem cells and platelets require oversight as biologic products by the Federal Drug Administration (FDA) under the Public Health Service Act and the Federal Food Drug and Cosmetic Act [137] [155].

As a cell-free therapy, the potential applications for the use of EVs in plastic surgery are being investigated through clinical trials because the diverse released bioactive constituents from exosomes and microvesicles display similar paracrine effects as growth factors and cytokines discharged from MSCs and activated platelets. The use of EVs biochemical products over cell-based therapies are the following: alternative to cell-based therapies, allogenic usage, superior safety profile, less immunogenicity, "off-the-shelf" strategy, stability and scalability [156] [157] [158]. The data obtained thus far has established EVs as novel players in mediated-horizontal transfer of a cargo of growth factors, cytokines, chemokines, proteins, lipids and nucleic acids for gene regulation, immune evasion, disease formation, tissue healing, growth and development.

The potential therapeutic benefits and mechanisms of action of MSC-derived EVs are being recognized to-date in some of the following pre-clinical studies and early clinical applications for plastic surgery. The finding that vesicles facilitate intercellular exchange of biomolecules may have important implications for the development a new class of therapeutics and regulatory pathways [159].

1) Vascular Biology: One of the best characterized roles of EVs is their capacity to enhance hemostasis, angiogenesis, and suppress endothelial cell senescence [160] [161] [162] [163].

2) Immunology: The diverse immunomodulatory properties of MSC-EVs include the paracrine messaging as pro-inflammatory mediators in infections, sepsis, and chronic inflammatory diseases [164] [165] [166].

3) Wound Healing: MSC-EVs have been demonstrated improve wound repair and to increase re-epithelialization, promote skin cell proliferation and inhibit apoptosis [167]-[172].

4) Biofilm: Bacterial outer membrane vesicles (OMVs) have been shown to contain proteins and other biomolecules that play a role in the formation and maintenance of the extracellular matrix contributing to biofilm formation and stability [173] [174].

5) Adipose Tissue: MSC-EVs have been shown to increase fat graft survival and browning from white cells [175] [176] [177].

6) Cartilage and Bone Healing: MSc-EVs have been found to increase chondrocyte growth and bone regeneration after degenerative disease and trauma [178] [179] [180] [181] [182].

7) Hair Growth: EVs have resulted in increased hair growth density, shaft diameters and pigmentation [183] [184] [185] [186] [187]. 


\section{Summary and Future Directions}

Stem cell-based research and therapies are currently being conducted worldwide with the underlying mechanisms for cellular proliferation, differentiation and homeostasis significantly achieved through paracrine functions of lipids, proteins, mRNAs, microRNAs, and bioactive molecules (growth factors, cytokines). In recent years, increasing attention has been given to the roles of extracellular vehicles not only in causing diseases but also in promoting normal physiological homeostasis and regenerative repair. Although the applications of cell-free therapy over cell therapy have been discussed, there exist major hurdles in both fields that include lack of standardization, molecular characterization, purity and reproducibility. Regarding clinical applications for safety and effectiveness, the active biological agents or cells used in both regenerative therapies are not FDA-approved and therefore under strict FDA regulation for their isolation, quality of production, and clinical usage. Future EVs studies and clinical experience in Plastic Surgery should focus on mechanisms by which EVs ameliorate diseases and aging, and, through evidence-based research, develop protocols and guidelines for the different use of stem-cell-derived EVs, while working within the current regulatory pathways.

\section{Funding}

The author has received an unrestricted grant from Direct Biologics for clinical research on exosome therapy.

\section{Conflicts of Interest}

The author declares no conflicts of interest.

\section{References}

[1] Thomas, E.D., Lochte, H.L., Lu, W.C., et al. (1957) Intravenous Infusion of Bone Marrow in Patients Receiving Radiation and Chemotherapy. New England Journal of Medicine, 257, 491-496. https://doi.org/10.1056/NEJM195709122571102

[2] Donald, G.P. and Darwin, J.P. (2007) Concise Review: Mesenchymal Stem/Multipotent Stromal Cells: The State of Transdifferentiation and Modes of Tissue Repair-Current View. Stem Cells, 25, 2896-2902. https://doi.org/10.1634/stemcells.2007-0637

[3] Nishida, K., Yamato, M., Hayashida, Y., et al. (2004) Corneal Reconstruction with Tissue-Engineered Cell Sheets Composed of Autologous Oral Mucosal Epithelium. New England Journal of Medicine, 351, 1187-1196. https://doi.org/10.1056/NEJMoa040455

[4] Zhou, H., Guo, M., Bian, C., et al. (2010) Efficacy of Bone Marrow-Derived Mesenchymal Stem Cells in the Treatment of Sclerodermatous Chronic Graft-Versus-Host Disease: Clinical Report. Biology of Blood and Marrow Transplantation, 16, 403-412. https://doi.org/10.1016/j.bbmt.2009.11.006

[5] Yoshimura, K., Suga, H. and Eto, H. (2009) Adipose-Derived Stem/Progenitor Cells, Roles in Adipose Tissue Remodeling and Potential Use for Soft Tissue Augmentation. Regenerative Medicine, 4, 265-273. https://doi.org/10.2217/17460751.4.2.265

[6] Harrison, J.H., Merrill, J.P. and Murray, J.E. (1956) Renal Homotransplantation in 
Identical Twins. Surgical Forum, 6, 432-436.

[7] Caplan, A.I. (2007) Adult Mesenchymal Stem Cells for Tissue Engineering versus Regenerative Medicine. Journal of Cellular Physiology, 213, 341-347.

https://doi.org/10.1002/jcp.21200

[8] Wong, V.W., Rustad, K.C., Longaker, M.T. and Gurtner, G.C. (2010) Tissue Engineering in Plastic Surgery: A Review. Plastic and Reconstructive Surgery, 126, 858-868. https://doi.org/10.1097/PRS.0b013e3181e3b3a3

[9] Beeson, W., Woods, E. and Agha R. (2011) Tissue Engineering, Regenerative Medicine, and Rejuvenation in 2010: The Role of Adipose-Derived Stem Cells. Facial Plas tic Surgery, 27, 378-388. https://doi.org/10.1055/s-0031-1283056

[10] Han, F., Jia, X., Dai, D., et al. (2013) Performance of a Multi-Layered Small-Diameter Vascular Scaffold Dual-Loaded with VEGF and PDGF. Biomaterials, 34, 7302-7313. https://doi.org/10.1016/j.biomaterials.2013.06.006

[11] Thevenot, P.T., Nair, A.M., Shen, J., et al. (2010) The Effects of Incorporation of SDF-1 $\alpha$ into PLGA Scaffolds on Stem Cell Recruitment and the Inflammatory Response. Biomaterials, 31, 3997-4008.

https://doi.org/10.1016/j.biomaterials.2010.01.144

[12] Mittelbrunn, M. and Sanchez-Madrid, F. (2012) Intercellular Communication: Diverse Structures for Exchange of Genetic Information. Nature Reviews Molecular Cell Biology, 13, 328-335. https://doi.org/10.1038/nrm3335

[13] Pittenger, M.F., Mackay, A.M., Beck, S.C., et al. (1999) Multilineage Potential of Adult Human Mesenchymal Stem Cells. Science, 284, 143-147.

https://doi.org/10.1126/science.284.5411.143

[14] Zuk, P.A., Zhu, M., Mizuno, H., et al. (2001) Multilineage Cells from Human Adipose Tissue: Implications for Cell-Based Therapies. Tissue Engineering, 7, 211-228. https://doi.org/10.1089/107632701300062859

[15] Gimble, J.M., Guliak, F. and Bunnell, B.A. (2010) Clinical and Preclinical Translation of Cell-Base Therapies Using Adipose Tissue-Derived Cells. Stem Cell Research \& Therapy, 1, Article No. 19.

[16] Wang, S., Qu, X. and Zhao, R.C. (2011) Mesenchymal Stem Cells Hold Promise for Regenerative Medicine. Frontiers of Medicine, 5, 372-378. https://doi.org/10.1007/s11684-011-0164-4

[17] Doorn, J., Moll, G., Le Blanc, K., et al. (2012) Therapeutic Applications of Mesenchymal Stromal Cells: Paracrine Effects and Potential Improvements. Tissue Engineering Part B: Reviews, 18, 101-115. https://doi.org/10.1089/ten.teb.2011.0488

[18] Lim, P., Patel, S.A. and Rameshwar, P. (2011) Effective Tissue Repair and Immunomodulation by Mesenchymal Stem Cells within a Milieu of Cytokines. In: Gorodetsky, R. and Schafer, R., Eds., Stem Cell Based Tissue Repair, RSC Publications, Cambridge, UK, 346-365.

[19] Lavoie, J.R. and Rosu-Myles, M. (2013) Uncovering the Secretes of Mesenchymal Stem Cells. Biochimie Journal, 95, 2212-2221.

https://doi.org/10.1016/j.biochi.2013.06.017

[20] Szoke, K., Beckstrom, K.J. and Binchmann, H.E. (2012) Human Adipose Tissue as a Source of Cells with Angiogenic Potential. Cell Transplantation, 21, 235-250. https://doi.org/10.3727/096368911X580518

[21] Zhang, B., Yin, Y., Lai, R.C., Tan, S.S., Choo, A.B.H. and Lim, S.K. (2014) Mesenchymal Stem Cells Secrete Immunologically Active Exosomes. Stem Cells and Development, 23, 1233-1244. https://doi.org/10.1089/scd.2013.0479 
[22] Yu, B., Zhang, X. and Li, S. (2014) Exosomes Derived from Mesenchymal Stem Cells. International Journal of Molecular Sciences, 15, 4142-4157. https://doi.org/10.3390/ijms15034142

[23] Hong, K.Y., Yim, S., Kin, H.J., et al. (2018) The Fate of Adipose-Derived Stromal Cells during Angiogenesis and Adipogenesis after Cell-Assisted Lipotransfer. Plastic and Reconstructive Surgery, 141, 365-375. https://doi.org/10.1097/PRS.0000000000004021

[24] Zhu, X., Shi, W., Tai, W. and Liu, F. (2012) The Comparition of Biological Characteristics and Multilineage Differentiation of Bone Marrow and Adipose Derived Mesenchymal Stem Cells. Cell and Tissue Research, 350, 277-287. https://doi.org/10.1007/s00441-012-1453-1

[25] Pachon-Pena, B., Yu, G., Tucker, A., et al. (2007) Stromal Stem Cells from Adipose Tissue and Bone Marrow of Age-Matched Female Donors Display Distinct Immunophenotypic Profiles. Journal of Cellular Physiology, 212, 702-709.

[26] Puissant, B., Barreau, C., Bourin, P., et al. (2005) Immunomodulatory Effect of Human Adipose Tissue-Derived Adult Stem Cells: Comparison with Bone Marrow Mesenchymal Stem Cells. British Journal of Haematology, 129, 118-129. https://doi.org/10.1111/j.1365-2141.2005.05409.x

[27] Halme, G.D. and Kessler, D.A. (2006) FDA Regulations of Stem-Cell-Based Therapies. New England Journal of Medicine, 355, 1730-1735. https://doi.org/10.1056/NEJMhpr063086

[28] Slaper-Cortenback, I.C. (2008) Current Regulations for the Production of Multipotent Mesenchymal Stromal Cells for Clinical Application. Transfusion Medicine and Hemotherapy, 35, 295-298. https://doi.org/10.1159/000144043

[29] Banyard, D.A., Salibian, A.A., Widerow, A.D., et al. (2015) Implications for Human Adipose-Derived Stem Cells in Plastic Surgery. Journal of Cellular and Molecular Medicine, 19, 21-30. https://doi.org/10.1111/jcmm.12425

[30] Haarer, J., Johnson, C.L., Soeder, U. and Dahlke, M.H. (2015) Caveats of Mesenchymal Stem Cell Therapy in Solid Organ Transplantation. Transplantation International, 28, 1-9. https://doi.org/10.1111/tri.12415

[31] Poulos, J. (2018) The Limited Application of Stem Cells in Medicine: A Review. Stem Cell Research \& Therapy, 9, Article No. 1. https://doi.org/10.1186/s13287-017-0735-7

[32] Tkach, M. and Thery, C. (2016) Communication by Extracellular Vesicles: Where Are We and Where We Need to Go. Cell, 164, 1226-1233. https://doi.org/10.1016/j.cell.2016.01.043

[33] Chargaff, E. and West, R. (1946) The Biological Significance of the Thromboplastic Protein of Blood. Journal of Biological Chemistry, 166, 189-197. https://doi.org/10.1016/S0021-9258(17)34997-9

[34] Wolf, P. (1967) The Nature and Significance of Platelet Products in Human Plasma. British Journal of Haematology, 13, 269-288. https://doi.org/10.1111/j.1365-2141.1967.tb08741.x

[35] Pan, B.T. and Johnstone, R.M. (1983) Fate of the Transferrin Receptor during Maturation of Sheep Reticulocytes in Vitro: Selective Externalization of the Receptor. Cell, 33, 967-978. https://doi.org/10.1016/0092-8674(83)90040-5

[36] Johnstone, R.M., Adam, M., Hammond, J.R., et al. (1987) Vesicle Formation during Reticulocyte Maturation. Association of Plasma Membrane Activities with Released Vesicles (Exosomes). Journal of Biological Chemistry, 262, 9412-9420. 
https://doi.org/10.1016/S0021-9258(18)48095-7

[37] Valadi, H., Ekstrom, K., Bossios, A., et al. (2007) Exosome-Mediated Transfer of mRNAs and microRNAs Is a Novel Mechanism of Genetic Exchange between Cells. Nature Cell Biology, 9, 654-659. https://doi.org/10.1038/ncb1596

[38] Desdín-Micó, G. and Mittelbrunn, M. (2017) Role of Exosomes in the Protection of Cellular Homeostasis. Cell Adhesion \& Migration, 11, 127-134. https://doi.org/10.1080/19336918.2016.1251000

[39] Bobrie, A., Colombo, M., Raposo, G., et al. (2011) Exosome Secretion: Molecular Mechanisms and Roles in Immune Responses. Traffic, 12, 1659-1668.

https://doi.org/10.1111/j.1600-0854.2011.01225.x

[40] Gutzeit, C., Nagy, N., Gentile, M., et al. (2014) Exosomes Derived from Burkitt's lymphoma Cell Lines Induce Proliferation, Differentiation and Class-Switch Recombination in B Cells. Journal of Immunology, 192, 5852-5862. https://doi.org/10.4049/jimmunol.1302068

[41] Xu, D. and Tahara, H. (2013) The Role of Exosomes and microRNAs in Senescence and Aging. Advanced Drug Delivery Review, 65, 368-375.

https://doi.org/10.1016/j.addr.2012.07.010

[42] Yáñez-Mó, M., Siljander P.R., Andreu, Z., et al. (2015) Biological Properties of Extracellular Vesicles and Their Physiological Functions. Journal of Extracellular Vesicles, 4, Article ID: 27066.

[43] Granger, E., McNee, G., Allan, V., et al. (2014) The Role of the Cytoskeleton and Molecular Motors in Endosomal Dynamics. Seminars in Cell \& Developmental Biology, 31, 20-29. https://doi.org/10.1016/j.semcdb.2014.04.011

[44] Hemler, M.E. (2003) Tetraspanin Proteins Mediate Cellular Penetration, Invasion, and Fusion Events, and Define a Novel Type of Membrane Microdomain. Annual Review of Cell and Developmental Biology, 19, 397-422. https://doi.org/10.1146/annurev.cellbio.19.111301.153609

[45] Pan, B.T., Teng, K., Wu, C., et al. (1985) Electron Microscopic Evidence for Externalization of the Transferrin Receptor in Vesicular Form in Sheep Reticulocytes. Journal of Cell Biology, 101, 942-948. https://doi.org/10.1083/jcb.101.3.942

[46] Subra, C., Grand, D., Laulagnier, K., et al. (2010) Exosomes Account for VesicleMedicated Transcellular Transport of Activatable Phospholipases and Prostaglandins. Journal of Lipid Research, 51, 2105-2120. https://doi.org/10.1194/jlr.M003657

[47] Michael, A., Bajracharya, S.D., Yuen, P.S., et al. (2010) Exosomes from Human Saliva as a Source of microRNA Biomarkers. Oral Disease, 16, 34-38.

https://doi.org/10.1111/j.1601-0825.2009.01604.x

[48] Mittelbrunn, M.C., Gutierrez-Vasquez, C., Villarroya-Beltri, S., et al. (2011) Unidirectional Transfer of microRNA-Loaded Exosomes from T Cells to Antigen-Presenting Cells. Nature Communications, 2, Article No. 282. https://doi.org/10.1038/ncomms1285

[49] Guescini, M., Genedani, S., Stocchi, V., et al. (2010) Astrocytes and Glioblastoma Cells Release Exosomes Carrying mtDNA. Journal of Neural Transmission (Vienna), 117, Article No. 1. https://doi.org/10.1007/s00702-009-0288-8

[50] Thery, C., Amigorena, S., Roposo, G., et al. (2006) Isolation and Characterization of Exosomes from Cell Culture Supernatants and Biological Fluids. Current Protocols in Cell Biology, 30, 3.22.1-3.22.29. https://doi.org/10.1002/0471143030.cb0322s30

[51] Aalberts, M., van Dissel-Emiliani, F.M., van Adrichem, N.P., et al. (2012) Identification of Distinct Populations of Prostasomes that Differentially Express Prostate 
stem Cell Antigen, Annexin A1 and GLIPR2 in Humans. Biology of Reproduction, 86, Article No. 82. https://doi.org/10.1095/biolreprod.111.095760

[52] Conde-Vancells, J., Rodriguez-Suarez, E., Embade, N., et al. (2008) Characterization and Comprehensive Proteome Profiling of Exosomes Secreted by Hepatocytes. Jour nal of Proteome Research, 7, 5157-5166. https://doi.org/10.1021/pr8004887

[53] Witwer, K.W., Buzas, E.I., Bemis, L.T., et al. (2013) Standardization of Sample Collection, Isolation and Analysis methods in Extracellular Vesicle Subpopulations. Journal of Extracellular Vesicles, 2, Article No. 20360. https://doi.org/10.3402/jev.v2i0.20360

[54] Raposo, G., Nijman, H.W., Stoorvogel, W., et al. (1996) B Lymphocytes Secrete Antigen-Presenting Vesicles. Journal of Experimental Medicine, 183, 1161-1172. https://doi.org/10.1084/jem.183.3.1161

[55] Raposo, G. and Stoorvogen, W. (2013) Extracellular Vesicles: Exosomes, Microvesicles, and Friends. Journal of Cell Biology, 200, 373-383.

https://doi.org/10.1083/jcb.201211138

[56] van der Pol, E., Böing, A.N., Harrison, P., Sturk, A., Nieuwland, R. and Mattson, M.P. (2012) Classification, Functions, and Clinical Relevance of Extracellular Vesicles. Pharmacological Reviews, 64, 676-705. https://doi.org/10.1124/pr.112.005983

[57] Dragovic, R.A., Gardiner, C., Brooks, A.S., et al. (2011) Sizing and Phenotyping of Cellular Vesicles Using Nanoparticle Tracking Analysis. Nanomedicine, 7, 780-788. https://doi.org/10.1016/j.nano.2011.04.003

[58] Gyorgy, B., Modos, K., Pallinger, E., et al. (2011) Detection and Isolation of CellDerived Microparticles Are Compromised by Protein Complexes Resulting from Shared Biophysical Parameters. Blood, 117, e39-e48. https://doi.org/10.1182/blood-2010-09-307595

[59] Turiak, L., Misjak, P., Szabo, T.G., et al. (2011) Proteomic Characterization of Thymocytes-Derived Microvesicles and Apoptotic Bodies. Journal of Proteomics, 74, 2025-2033. https://doi.org/10.1016/j.jprot.2011.05.023

[60] Marzesco, A.M., Janich, P., Wilsch-Brauninger, M., et al. (2005) Release of Extracellular Membrane Particles Carrying Stem Cell Marker Prominin-1 (CD133) from Neural Progenitors and Other Epithelial Cells. Journal of Cell Science, 118, 2849-2858. https://doi.org/10.1242/jcs.02439

[61] Hristov, M., Erl, W., Linder, S., et al. (2004) Apoptotic Bodies from Endothelial Cells Enhance the Number and Initiate the Differentiation of Human Endothelial Progenitor Cells in Vitro. Blood, 104, 2761-2766.

https://doi.org/10.1182/blood-2003-10-3614

[62] Thery, C., Ostrowski, M. and Segura, E. (2009) Membrane Vesicles as Conveyers of Immune Responses. Nature Reviews Immunology, 9, 581-593. https://doi.org/10.1038/nri2567

[63] Palma, J., Yaddanapudi, S.C., Pigati, L., et al. (2012) MicroRNAs Are Exported from Malignant Cells in Customized Particles. Nucleic Acids Research, 40, 9125-9138. https://doi.org/10.1093/nar/gks656

[64] Mathivanan, S., Fahner, C.J., Reid, G.E., et al. (2012) ExoCarta 2012: Database of Exosomal Proteins, RNA, and Lipids. Nucleic Acids Research, 40, D1242-1244. https://doi.org/10.1093/nar/gkr828

[65] Kalra, H., Simpson, R.J., Ji, H., et al. (2012) Vesiclepedia: A Compendium for Extracellular Vesicles with Continuous Community Annotation. PLoS Biology, 10, e1001450. https://doi.org/10.1371/journal.pbio.1001450 
[66] Colombo, M., Raposo, G. and Thery, C. (2014) Biogenesis, Secretion, and Intercellular Interactions of Exosomes and Other Extracellular Vesicles. Annual Review of Cell and Developmental Biology, 30, 255-289.

https://doi.org/10.1146/annurev-cellbio-101512-122326

[67] Record, M., Carayon, K., Poirot, M., et al. (2014) Exosomes as New Vesicular Lipid Transporters Involved in Cell-Cell Communication and Various Pathophysiologies. Biochimica et Biophysica Acta, 1841, 108-120. https://doi.org/10.1016/j.bbalip.2013.10.004

[68] Ikonen, E. (2001) Roles of Lipid Rafts in Membrane Transport. Current Opinion in Cell Biology, 13, 470-477. https://doi.org/10.1016/S0955-0674(00)00238-6

[69] Simons, K. and Sampaio, J.L. (2011) Membrane Organization and Lipid Rafts. Cold Spring Harbor Perspective in Biology, 3, a004697.

https://doi.org/10.1101/cshperspect.a004697

[70] Llorente, A., van Deurs, B. and Sandvig, K. (2007) Cholesterol Regulates Prostasome Release from Secretory Lysosomes in PC-3 Human Prostate Cancer Cells. European Journal of Cell Biology, 86, 405-415.

https://doi.org/10.1016/j.ejcb.2007.05.001

[71] Ratajczak, J., Miedus, K., Kucia, M., et al. (2006) Embryonic Stem Cell-Derived Microvesicles Reprogram Hematopoietic Progenitors: Evidence for Horizontal Transfer of mRNA and Protein Delivery. Leukemia, 20, 847-856.

https://doi.org/10.1038/sj.leu.2404132

[72] Baj-Krzyworzeka, M., Szatanek, R., Weglarczyk, K., et al. (2006) Tumor-Derived Microvesicles Carry Several Surface Determinants and mRNA of Tumour Cells and Transfer Some of These Determinants to Monocytes. Cancer Immunology, Immunotherapy, 55, 808-818. https://doi.org/10.1007/s00262-005-0075-9

[73] Batagov, A.O. and Kurochkin, I.V. (2013) Exosomes Secreted by Human Cells Transport Largely mRNA Fragments that Are Enriched in the 3'-Untranslated Regions. Biology Direct, 8, Article No. 12. https://doi.org/10.1186/1745-6150-8-12

[74] Huang, X., Yuan, T., Tschannen, M., et al. (2013) Characterization of Human Plasma-Derived Exosomal RNAs by Deep Sequencing. BMC Genomics, 14, Article No. 319. https://doi.org/10.1186/1471-2164-14-319

[75] Bellingham, S.A., Coleman, B.M. and Hill, A.F. (2012) Small RNA Deep Sequencing Reveals a Distinct miRNA Signature Released in Exosomes from Prion-Infected Neuronal Cells. Nucleic Acids Research, 40, 10937-10949. https://doi.org/10.1093/nar/gks832

[76] Crescitelli, R., Lasser, C., Szabo, T.G., et al. (2013) Distinct RNA Profiles in Subpopulations of Extracellular Vesicles: Apoptotic Bodies, Microvesicles and Exosomes. Journal of Extracellular Vesicles, 2, Article No. 20677.

https://doi.org/10.3402/jev.v2i0.20677

[77] Nolte-'t Hoen, E.N., Buermans, H.P., Waasdorp, M., et al. (2012) Deep Sequencing of RNA from Immune Cell-Derived Vesicles Uncovers the Selective Incorporation of Small Non-Coding RNA Biotypes with Potential Regulatory Functions. Nucleic Acids Research, 40, 9272-9285. https://doi.org/10.1093/nar/gks658

[78] Villarroya-Beltri, C., Baixauli, F., Gutierrez-Vazquez, C., et al. (2014) Sorting It Out: Regulation of Exosome Loading. Seminars in Cancer Biology, 28, 3-13. https://doi.org/10.1016/j.semcancer.2014.04.009

[79] Ostenfeld, M.S., Jeppensen, D.K., Laurberg, J.R., et al. (2014) Cellular Disposal of miR23b by RAB27-Depent Exosome Release Is Linked to Acquisition of Metastatic Properties. Cancer Research, 74, 5758-5771. 
https://doi.org/10.1158/0008-5472.CAN-13-3512

[80] Deregibus, M.C., Cantaluppi, V., Calogero, R., et al. (2007) Endothelial Progenitor Cell Derived Microvesicles Activate an Angiogenic Program in Endothelial Cells by a Horizontal Transfer of mRNA. Blood, 110, 2440-2448. https://doi.org/10.1182/blood-2007-03-078709

[81] Bruno, S., Grange, C., Collino, F., et al. (2012) Microvesicles Derived from Mesenchymal Stem Cells Enhance Survival in a Lethal Model of Acute Kidney Injury. PLoS ONE, 7, e33115. https://doi.org/10.1371/journal.pone.0033115

[82] Bruno, S., Grange, C., Deregibus, M.C., et al. (2009) Mesenchymal Stem Cell-Derived Microvesicles Protect against Acute Tubular Injury. Journal American Society of Nephrology, 20, 1053-1067. https://doi.org/10.1681/ASN.2008070798

[83] Muller, G., Schneider, M., Biemer-Daub, G., et al. (2011) Microvesicles Released from Rat Adipocytes and Harboring Glycosylphosphatidylinositol-Anchored Proteins Transfer RNA Stimulating Lipid Synthesis. Cellular Signalling, 23, 1207-1223. https://doi.org/10.1016/j.cellsig.2011.03.013

[84] Ogawa, R., Tanaka, C., Sato, M., et al. (2010) Adipocyte-Derived Microvesicles Contain RNA That Is Transported into Macrophages and Might Be Secreted into Blood Circulation. Biochemisty and Biophysics Research Communications, 398, 723-729. https://doi.org/10.1016/j.bbrc.2010.07.008

[85] Fernandez-Messina, L., Gutierrez-Vasquez, C., Rivas-Garcia, E., et al. (2015) Immunomodulatory Role of microRNAs Transferred by Extracellular Vesicles. Biological Cell, 107, 61-77. https://doi.org/10.1111/boc.201400081

[86] Forterre, A., Jalabert, A., Chikh, K., et al. (2014) Myotube-Derived Exosomal miRNAs Downregulate Sirtuin1 in Myoblasts during Muscle Cell Differentiation. Cell Cycle, 13, 78-89. https://doi.org/10.4161/cc.26808

[87] Xu, J.F., Yang, G.H., Pan, X.H., et al. (2014) Altered microRNA Expression Profile in Exosomes during Osteogenic Differentiation of Human Bone Marrow-Derived Mesenchymal Stem Cells. PLoS ONE, 9, e114627. https://doi.org/10.1371/journal.pone.0114627

[88] Holmgren, L., Szeles, A., Rajnavolgyi, E., et al. (1999) Horizontal Transfer of DNA by the Uptake of Apoptotic Bodies. Blood, 93, 3956-3963. https://doi.org/10.1182/blood.V93.11.3956.411k05_3956_3963

[89] Lee, T.H., Chennakrishnaiah, S., Audemard, E., et al. (2014) Oncogenic Ras-Driven Cancer Cell Vesiculation Leads to Emission of Double-Stranded DNA Capable of Interacting with Target Cells. Biochemistry and Biophysics Research Communications, 451, 295-301. https://doi.org/10.1016/j.bbrc.2014.07.109

[90] Waldenstrom, A., Genneback, N., Hellman, U., et al. (2012) Cardiomyocyte Microvesicles Contain DNA/RNA and Convey Biological Messages to Target Cells. PLoS ONE, 7, e34653. https://doi.org/10.1371/journal.pone.0034653

[91] Lazaro-Ibanez, E., Sanz-Garcia, A., Visakorpi, T., et al. (2014) Different gDNA Content in the Subpopulations of Prostate Cancer Extracellular Vesicles: Apoptotic bodies, Microvesicles, and Exosomes. Prostate, 74, 1379-1390. https://doi.org/10.1002/pros.22853

[92] Kilpinen, L., Impola, U., Sankkila, L., et al. (2013) Extracellular Membrane Vesicles from Umbilical Cord Blood-Derived MSC Protect against Ischemic Acute Kidney Injury, a Feature that Is Lost after Inflammatory Conditioning. Journal Extracellular Vesicles, 2, Article No. 21927. https://doi.org/10.3402/jev.v2i0.21927

[93] Salomon, C., Ryan, J., Sobrevia, L., et al. (2013) Exosomal Signaling during Hypoxia mediates Microvascular Endothelial Cell Migration and Vasculogenesis. PLoS ONE, 
8, e68451. https://doi.org/10.1371/journal.pone.0068451

[94] Rani, S., Ryan, A.E., Griffen, D., et al. (2015) Mesenchymal Stem Cell-Derived Extracellular Vesicles: Toward Cell-Free Therapeutic Applications. Molecular Therapy, 23, 812-823. https://doi.org/10.1038/mt.2015.44

[95] Batista, B.S., Eng, W.S., Pilobello, K.T., et al. (2011) Identification of a Conserved glycan Signature for Microvesicles. Journal of Proteome Research, 10, 4624-4633. https://doi.org/10.1021/pr200434y

[96] Hagerstrand, H., Mrowczynska, L., Salzer, U., et al. (2006) Curvature-Dependent lateral Distribution of Raft Markers in the Human Erythrocyte Membrane. Molecular Membrane Biology, 23, 277-288. https://doi.org/10.1080/09687860600682536

[97] Kralj-Iglic, V. and Veranic, P. (2006) Curvature-Induced Sorting of Bilayer Membrane Constituents and Formation of Membrane Rafts. Advances in Planar Lipid Bilayers and Liposomes, 5, 129-149. https://doi.org/10.1016/S1554-4516(06)05005-8

[98] Perez-Hernandez, D., Gutierrez-Vazquez, C., Jorge, I., et al. (2013) The Intracellular Interactome of Tetraspanin-Enriched Microdomains Reveals Their Function as Sorting Machineries toward Exosomes. Journal of Biological Chemistry, 288, 11649-11661. https://doi.org/10.1074/jbc.M112.445304

[99] Bari, R., Guo, Q., Xia, B., et al. (2011) Tetraspanins Regulate the Protrusive Activities of Cell Membrane. Biochemical and Biophysical Research Communications, 415, 619-626. https://doi.org/10.1016/j.bbrc.2011.10.121

[100] Andreu, Z. and Yáñez-Mó, M. (2014) Tetraspanins in Extracellular Vesicle Formation and Function. Frontiers in Immunology, 5, 442.

https://doi.org/10.3389/fimmu.2014.00442

[101] Trajkovic, K., Hsu, C., Chiantia, S., et al. (2008) Ceramide Triggers Budding of Exosome Vesicles into Multivesicular Endosomes. Science, 319, 1244-1247. https://doi.org/10.1126/science.1153124

[102] Van Niel, G., Charrin, S., Simoes, S., et al. (2011) The Tetraspanin CD63 Regulates ESCRT-Independent and Dependent Endosomal Sorting during Melanogenesis. Developmental Cell, 21, 708-721. https://doi.org/10.1016/j.devcel.2011.08.019

[103] Metcalf, D. and Isaacs, A.M. (2010) The Role of ESCRT Proteins in Fusion Events Involving Lysosomes, Endosomes, and Autophagosomes. Biochemical Society Translations, 38, 1469-1473. https://doi.org/10.1042/BST0381469

[104] Wollert, T., Wunder, C., Lippincotte-Schwartz, J., et al. (2009) Membrane Scission by the ESCRT-III Complex. Nature, 458, 172-177.

https://doi.org/10.1038/nature07836

[105] Hanson, P.I. and Cashikar, A. (2012) Multivesicular Body Morphogenesis. Annual Review of Cellular Developmental Biology, 28, 337-362. https://doi.org/10.1146/annurev-cellbio-092910-154152

[106] Baietti, M.F., Zhang, Z., Mortier, E., et al. (2012) Syndecan-Syntenin-ALIX Regulates the Biogenesis of Exosomes. Nature Cell Biology, 14, 677-685.

https://doi.org/10.1038/ncb2502

[107] Ghossoub, R., Lembo, F., Rubio, A., et al. (2014) Syntenin-ALIX Exosome Biogenesis and Budding into Multivesicular Bodies Are Controlled by ARF6 and PLD2. Nature Communications, 5, Article No. 3477. https://doi.org/10.1038/ncomms4477

[108] Sala-Valdes, M., Ursa, A., Charrin, S., et al. (2006) EWI2 and EWI-F Link the Transpanin Web to the Actin Cytoskeleton through Their Direct Association with Ezrin-Radixin-Moesin Proteins. Journal of Biological Chemistry, 281, 19665-19675. https://doi.org/10.1074/jbc.M602116200 
[109] Huber, L.A. and Teis, D. (2016) Lysosomal Signaling in Control Degradation Pathways. Current Opinion in Cell Biology, 39, 8-14.

https://doi.org/10.1016/j.ceb.2016.01.006

[110] Desdín-Micó, G. and Mittelbrunn, M. (2017) Role of Exosomes in the Protection of Cellular Homeostasis. Cell Adhesion and Migration, 11, 127-134. https://doi.org/10.1080/19336918.2016.1251000

[111] Ratajck, J., Wysoczynski, M., Hayek, F., et al. (2006) Membrane-Derived Microvesicles: Important and Underappreciated Mediators of Cell-to-Cell Communication. Leukemia, 20, 1487-1495. https://doi.org/10.1038/sj.leu.2404296

[112] Bilyy, R.O., Shkanndina, T., Tomin, A., et al. (2012) Macrophages Discriminate Glycosylation Patterns of Apoptotic Cell-Derived Microparticles. Journal of Biological Chemistry, 287, 494-503. https://doi.org/10.1074/jbc.M111.273144

[113] Cai, H., Reinisch, K. and Ferro-Novick, S. (2007) Coats, Tethers, Rabs, and SNAREs Work Together to Mediate the Intracellular Destinations of a Transport Vesicle. Developmental Cell, 12, 671-682. https://doi.org/10.1016/j.devcel.2007.04.005

[114] Savina, A., Vidal, M. and Colombo, M.I. (2002) The Exosome Pathway in K562 Cells Is Regulated by Rab11. Journal of Cell Science, 115, 2505-2515. https://doi.org/10.1242/jcs.115.12.2505

[115] Stenmark, H. (2009) Rab GTPases as Coordinators of Vesicle Traffic. National Reviews Molecular Cell Biology, 10, 513-525. https://doi.org/10.1038/nrm2728

[116] Rana, S., Yue, S., Stadel, D., et al. (2012) Toward Tailored Exosomes: The Exosomal Tetraspanin Web Contributes to Target Cell Selection. International Journal of Biochemistry and Cell Biology, 44, 1574-1584. https://doi.org/10.1016/j.biocel.2012.06.018

[117] Segura, E., Guerin, C., Hoff, N., et al. (2007) CD8 ${ }^{+}$Dendritic Cells Use LFA-1 to Capture MHC-Peptide Complexes from Exosomes in Vivo. Journal of Immunology, 179, 1489-1496. https://doi.org/10.4049/jimmunol.179.3.1489

[118] Mulcahy, L.A., Pink, R.C. and Carter, D.R.F. (2014) Routes and Mechanisms of Extracellular Vesicle Uptake. Journal of Extracellular Vesicles, 3, Article No. 24641. https://doi.org/10.3402/jev.v3.24641

[119] Abrami, L., Brandi, L., Moayeri, et al. (2013) Hijacking Multivesicular Bodies Enables Long-Term and Exosome-Mediated Long-Distance Action of Anthrax Toxin. Cell Reports, 5, 986-996. https://doi.org/10.1016/j.celrep.2013.10.019

[120] Owen, M. (1988) Marrow Stromal Stem Cells. Journal of Cell Science, 10, 63-76. https://doi.org/10.1242/jcs.1988.Supplement_10.5

[121] Caplan, A.I. (1991) Mesenchymal Stem Cells. Journal of Orthopaedic Research, 9, 641-650. https://doi.org/10.1002/jor.1100090504

[122] Horwitz, E.M., Le Blanc, K., Dominici, M., et al. (2005) Clarification of the Nomenclature for MSC: The International Society for Cellular Therapy Position Statement. Cytotherapy, 7, 393-395. https://doi.org/10.1080/14653240500319234

[123] Dominici, M., Le Blanc, K., Mueller, I., et al. (2006) Minimal Criteria for Defining Multipotent Mesenchymal Stromal Cells. The International Society for Cellular Therapy Position Statement. Cryotherapy, 8, 315-317. https://doi.org/10.1080/14653240600855905

[124] Bernardo, M.E., Locatelli, F. and Fibbe, W.E. (2009) Mesenchymal Stromal Cells. Annals of the New York Academy of Sciences, 1176, 101-117. https://doi.org/10.1111/j.1749-6632.2009.04607.x

[125] Prockop, D.J., Brenner, M., Fibbe, W.E., et al. (2010) Defining the Risks of Mesen- 
chymal Stromal Cell Therapy. Cytotherapy, 12, 576-578. https://doi.org/10.3109/14653249.2010.507330

[126] Kasper, B., Dankert, N., Tuischer, J., et al. (2007) Mesenchymal Stem Cells Regulate Angiogenesis According Their Mechanical Environment. Stem Cells, 25, 903-910. https://doi.org/10.1634/stemcells.2006-0432

[127] Horwitz, E.M. and Dominici, M. (2008) How Do Mesenchymalstromal Cells Exert Their Therapeutic Benefit? Cytotherapy, 10, 771-774.

https://doi.org/10.1080/14653240802618085

[128] Rasmusson, I., Ringden, O., Sundberg, B., et al. (2005) Mesenchymal Stem Cells Inhibit Lymphocyte Proliferation by Mitogens and Alloantigens by Different $\mathrm{Me}$ chanisms. Experimental Cell Research, 305, 33-41.

https://doi.org/10.1016/j.yexcr.2004.12.013

[129] da Silva Meirelles, L., Fontes, A.M., Covas, D.T., et al. (2009) Mechanisms Involved in the Therapeutic Properties of Mesenchymal Stem Cells. Cytokine \& Growth Factor Reviews, 20, 419-427. https://doi.org/10.1016/j.cytogfr.2009.10.002

[130] Le Blanc, K., Frassoni, F., Ball, L., et al. (2008) Mesenchymal Stem Cells for Treatment of Steroid-Resistant, Severe, Acute Graft-versus-Host Disease: A Phase II Study. The Lancet, 371, 1578-1586. https://doi.org/10.1016/S0140-6736(08)60690-X

[131] Mallam, E., Kemp, K., Wilkins, A., et al. (2010) Characterization of in Vitro Expanded Bone Marrow-Derived Mesenchymal Stem Cells from Patients with Multiple Sclerosis. Multiple Sclerosis Journal, 62, 909-918.

https://doi.org/10.1177/1352458510371959

[132] Kuroda, R., Ishida, K., Matsumoto, T., et al. (2007) Treatment of a Fullothickness Articular Cartilage Defect in the Femoral Condyle of an Athlete with Autologous Bone-Marrow Stromal Cells. Osteoarthritis and Cartilage, 15, 226-231. https://doi.org/10.1016/j.joca.2006.08.008

[133] Hare, J.M., Traverse, J.H., Henry, T.D., et al. (2009) A Randomized, Double-Blind, Placebo-Controlled, Dose-Escalation Study of Intravenous Adult Human Mesenchymal Stem Cells (Prochymal) after Acute Myocardial Infarction. Journal of the American College of Cardiology, 54, 2277-2288. https://doi.org/10.1016/j.jacc.2009.06.055

[134] Anna, G., John, D., Jean, F., et al. (2008) Initial Report on a Phase I Clinical Trial: Prevention and Treatment of Post-Operative Acute Kidney Injury with Allogeneic Mesenchymal Stem Cells in Patients Who Require on-Pump Cardiac Surgery. Cellular Therapy and Transplantation, 1, 31-35.

[135] Gir, P., Brown, S.A., Oni, G., et al. (2012) Fat Grafting: Evidence-Based Review on Autologous Fat Harvesting, Processing, Reinjection, and Storage. Plastic and Reconstructive Surgery, 130, 249-258. https://doi.org/10.1097/PRS.0b013e318254b4d3

[136] Sasaki, G.H. (2015) Plastic Surgery Update on the Biology of Fat Cells and Adipose-Derived Stem Cells for Fat Grafting. Open Access Library Journal, 2, e1505.

[137] Halme, D.G. and Kessler, D.A. (2006) FDA Regulation of Stem Cell-Based Therapies. New England Journal of Medicine, 355, 1730-1735. https://doi.org/10.1056/NEJMhpr063086

[138] Daher, S.R., Johnstone, B.H., Phinney, D.G., et al. (2008) Adipose Stromal/Stem Cells: Basic and Translational Advances: The IFATS Collection. Stem Cells, 26, 2664-2665. https://doi.org/10.1634/stemcells.2008-0927

[139] Chang, Q., Li, J., Dong, Z., et al. (2013) Quantitative Volumetric Analysis of Progressive Hemifacial Atrophy Corrected Using Stromal Vascular Fraction-Supplemented Autologous Fat Grafts. Dermatological Surgery, 39, 1465-1473. 
[140] Yoshimura, K., Sato, K., Aoi, N., et al. (2008) Cell-Assisted Lipotransfer for Cosmetic Breast Augmentation: Supportive Use of Adipose-Derived Stem/Stromal Cells. Aesthetic Plastic Surgery, 32, 48-55. https://doi.org/10.1007/s00266-007-9019-4

[141] Tiryaki, T. and Findikli, D. (2008) Staged Stem Cell-Enriched Tissue (SET) Injections for Sort Tissue Augmentation in Hostile Recipient Areas: A Preliminary Report. Aesthetic Plastic Surgery, 35, 965-971. https://doi.org/10.1007/s00266-011-9716-x

[142] Sasaki, G.H. (2015) The Safety and Efficacy of Cell-Assisted Fat Grafting to Traditional Fat Grafting in the Anterior Mid-Face: An Indirect Assessment by 3D Imaging. Aesthetic Plastic Surgery, 39, 833-846.

https://doi.org/10.1007/s00266-015-0533-5

[143] Peltoniemi, H.H., Salmi, A., Miettinen, S., et al. (2013) Stem Cell Enrichment Does Not Warrant a Higher Graft Survival in Lipofilling of the Breast: A Prospective Comparative Study. Journal of Plastic Reconstructive Aesthetic Surgery, 66, 1494-1503. https://doi.org/10.1016/j.bjps.2013.06.002

[144] Sterodemas, A., de Faria, J., Nicaretta, B., et al. (2011) Autologous Fat Transplantation Versus Adipose-Derived Stem Cell-Enriched Lipografts: A Study. Aesthetic Surgical Journal, 31, 682-693. https://doi.org/10.1177/1090820X11415976

[145] Alexander, R.W. (2016) Understanding Mechanical Emulsification (Nanofat) versus Enzymatic Isolation of Tissue Stromal Vascular Fraction (tSVF) Cells from Adipose Tissue: Potential Uses in Biocellular Regenerative Medicine. Journal of Prolotherapy, 8, e947-e960.

[146] Tonnard, P., Verpaele, A., Peeters, G., et al. (2013) Nanofat Grafting: Basic Research and Clinical Applications. Plastic and Reconstructive Surgery, 132, 1017-1026. https://doi.org/10.1097/PRS.0b013e31829fe1b0

[147] Conde-Green, A., Rodriguez, R.L., Slezak, S., et al. (2014) Comparison between Stromal Vascular Cells' Isolation with Enzymatic Digestion and Mechanical Processing of Aspirated Adipose Tissue. Plastic and Reconstructive Surgery, 134, 54. https://doi.org/10.1097/01.prs.0000455394.06800.62

[148] Oberbauer, E., Steffenhagen, C., Wurzer, C., et al. (2015) Enzymatic and Non-Enzymatic Isolation Systems for Adipose Tissue-Derived Cells: Current State of the Art. Cell Regeneration, 4, 7. https://doi.org/10.1186/s13619-015-0020-0

[149] Conde-Green, A., Kotamarti, V.S., Sherman, L.S., et al. (2016) Shift toward Mechanical Isolation of Adipose-Derived Stromal Vascular Fraction: Review of Upcoming Techniques. Plastic and Reconstructive Surgery, 4, e1017. https://doi.org/10.1097/GOX.0000000000001017

[150] Cohen, S.R., Tiryaki, T., Womack, H., et al. (2019) Cellular Optimization of Nanofat: Comparison of Two Nanofat Processing Devices in Terms of Cell Count and Viability. Aesthetic Surgery Journal Open Forum, 1, Article ID: ojz028. https://doi.org/10.1093/asjof/ojz028

[151] Marx, R.E. (2004) Platelet-Rich Plasma: Evidence to Support Its Use. Journal of Oral and Maxillofacial Surgery, 62, 489-496.

https://doi.org/10.1016/j.joms.2003.12.003

[152] Sadati, K.S., Corrado, A.C. and Alexander, R.W. (2006) Platelet-Rich Plasma (PRP) Utilized to Promote Greater Graft Retention in Autologous Fat Grafting. American Journal of Cosmetic Surgery, 23, 203-211. https://doi.org/10.1177/074880680602300407

[153] Cervilli, V., Gentile, P., Scioli, M.G., et al. (2009) Application of Platelet-Rich Plasma in Plastic Surgery: Clinical and in Vitro Evaluation. Tissue Engineering Part C: 
Methods, 15, 625-634. https://doi.org/10.1089/ten.tec.2008.0518

[154] Sasaki, G.H. (2019) A Preliminary Clinical Trial Comparing Split Treatments to the Face and Hand with Autologous Fat Grafting and Platelet-Rich Plasma (PRP): A 3D, IRB Approved Study. Aesthetic Surgery Journal, 39, 675-686. https://doi.org/10.1093/asj/sjy254

[155] Centeno, C.J., Fuerst, N., Faulkner, S.J., et al. (2011) Is Cosmetic Platelet-Rich Plasm a Drug to Be Regulated by the Food and Drug Administration? Journal of Cosmetic Dermatology, 10, 171-173. https://doi.org/10.1111/j.1473-2165.2011.00575.x

[156] Hessvik, N.P. and Llorent, A. (2018) Current Knowledge on Exosome Biogenesis and Release. Cellular and Molecular Life Sciences, 75, 193-208.

https://doi.org/10.1007/s00018-017-2595-9

[157] De Jong, O.G., Van Valkom, B.M., Schiffelers, R.M., et al. (2014) Extracellular Vesicles: Potential Roles in Regenerative Medicine. Frontiers in Immunology, 5, Article No. 608. https://doi.org/10.3389/fimmu.2014.00608

[158] Whitford, W. and Guterstam, P. (2019) Exosome Manufacturing Status. Future Medical Chemistry, 11, 1225-1236. https://doi.org/10.4155/fmc-2018-0417

[159] Bersenev, A. (2016) Considerations for Clinical Translation of Extracellular Vesicles as New Class of Therapeutics. In: William, G. and Alexey, B., Eds., Stem Cell Assays, Department of Hematology Children's Hospital of Philadelphia, Philadelphia, USA.

[160] Owens, A.P. and Mackman, N. (2011) Microparticles in Hemostasis and Thrombosis. Circulation Research, 108, 1284-1297. https://doi.org/10.1161/CIRCRESAHA.110.233056

[161] Rhee, H.S., Black, M. and Schubert, U. (2004) The Functional Role of Blood Platelet Components in Angiogenesis. Thrombosis and Haemostasis, 92, 394-402. https://doi.org/10.1160/TH03-04-0213

[162] Zhu, W., Huang, L., Li, Y., et al. (2010) Exosomes Derived from Human Bone Marrow Mesenchymal Stem Cells Promote Tumor Growth in Vivo. Cancer Letters, 315, 28-37. https://doi.org/10.1016/j.canlet.2011.10.002

[163] van Balkom, B.W., de Jong, O.G., Smits ,M., et al. (2013) Endothelial Cells Require mR-214 to Secrete Exosomes that Suppress Senescence and Induce Angiogenesis in Human and Mouse Endothelial Cells. Blood, 121, 3997-4006. https://doi.org/10.1182/blood-2013-02-478925

[164] Cloutier, N., Tan, S., Boudreau, L.H., et al. (2013) The Exposure of Autoantigens by Microparticles Underlies the Formation of Potent Inflammatory Components: The Microparticle-Associated Immune Complexes. EMBO Molecular Medicine, 5, 235-249. https://doi.org/10.1002/emmm.201201846

[165] Ankrum, J.A., Ong, J.F. and Karp, J.M. (2014) Mesenchymal Stem Cells: Immune Evasive, Not Immune Privileged. Nature Biotechnology, 32, 1-9. https://doi.org/10.1038/nbt.2816

[166] Sengupta, V., Sengupta, S., Lazo, A., et al. (2020) Exosomes Derived from Bone Marrow Mesenchymal Stem Cells as Treatment for Severe COVID-19. Stem Cells and Development, 29, 747-754. https://doi.org/10.1089/scd.2020.0080

[167] Maxson, S., Lopex, E.A., Yoo, D., et al. (2010) Concise Review: Role of Mesenchymal Stem Cell in Wound Repair. Stem Cells Translational Medicine, 1, 142-149. https://doi.org/10.5966/sctm.2011-0018

[168] Hocking, A.M. and Gibran, N.S. (2010) Mesenchymal Stem Cells: Paracrine Signaling and Differentiation during Cutaneous Wound Repair. Experimental Cell Re- 
search, 316, 2213-2219. https://doi.org/10.1016/j.yexcr.2010.05.009

[169] Huang, S., Wu, Y., Gao, D., et al. (2015) Paracrine Action of Mesenchymal Stromal Cells Delivered by Microspheres Contributes to Cutaneous Wound Healing and Prevents Scar Formation in Mice. Cytotherapy, 17, 922-931. https://doi.org/10.1016/j.jcyt.2015.03.690

[170] Hu, L., Wang, J., Zhou, X., et al. (2016) Exosomes Derived from Human Adipose Mesenchymal Stem Cells Accelerates Cutaneous Wound Healing via Optimizing the Characteristics of Fibroblasts. Scientific Reports, 6, Article No. 32933. https://doi.org/10.1038/srep32993

[171] Zhang, B., Wand, M., Gong, A., et al. (2015) HucMSC-Exosome Mediated-Wnt4 Signaling Is Required for Cutaneous Wound Healing. Stem Cells, 33, 2158-2168. https://doi.org/10.1002/stem.1771

[172] Sasaki, G.H. (2017) Micro-Needling Depth Penetration, Presence of Pigment Particles, and Fluorescein-Stained Platelets: Clinical Usage for Aesthetic Concerns. Aesthetic Surgery Journal, 37, 71-83. https://doi.org/10.1093/asj/sjw120

[173] Schooling, S.R. and Beveridge, T.J. (2006) Membrane Vesicles: An Over-Looked Component of the Matrices of Biofilms. Journal of Bacteriology, 188, 5945-5957. https://doi.org/10.1128/JB.00257-06

[174] Yonezawa, H., Osaki, T., Kurata, S., et al. (2009) Outer Membrane Vesicles of Helicobacter Pylori TK1402 Are in Involved in Biofilm Formation. BMC Microbiology, 9, Article No. 197. https://doi.org/10.1186/1471-2180-9-197

[175] Garcia-Contreras, M., Messaggio, F., Jimenez, O., et al. (2014) Differences in Exosome Content of Human Adipose Tissue Processed by Non-Enzymatic and Enzymatic Methods. CellR4, 3, e1423.

[176] Chen, B., Cai, J., Wei, Y., et al. (2019) Exosomes Are Comparable to Source Adipose Stem Cells in Fat Graft Retention with Up-Regulating Early Inflammation and Angiogenesis. Plastic and Reconstructive Surgery, 144, 816e-827e. https://doi.org/10.1097/PRS.0000000000006175

[177] Zhu, Y., Zhang, J., Hu, X., et al. (2020) Supplementation with Extracellular Vesicles Derived from Adipose-Derived Stem Cells Increases Fat Graft Survival and Browning in Mice: A Cell-Free Approach to Construct Beige Fat from White Fat Grafting. Plastic and Reconstructive Surgery, 145, 1183-1195. https://doi.org/10.1097/PRS.0000000000006740

[178] Lu, K., Li, H., Yang, I., et al. (2017) Exosomes as Potential Alternatives to Stem Cell Therapy for Intervertebral Disc Degeneration: In Vitro Study on Exosomes Interaction of Nucleus Pulposus Cells and Bone Marrow Mesenchymal Stem Cells. Stem Cell Research \& Therapy, 8, Article No. 108. https://doi.org/10.1186/s13287-017-0563-9

[179] Lin, Z., Rodriguez, N.E., Zhao, J., et al. (2016) Selective Enrichment of microRNAs in Extracellular Matrix Vesicles Produced by Growth Plate Chondrocytes. Bone, 88, 47-55. https://doi.org/10.1016/j.bone.2016.03.018

[180] Liu, X., Yang, Y., Li, Y., et al. (2017) Integration of Stem Cell-Derived Exosomes with in Situ Hydrogen Glue as a Promising Tissue Patch for Articular Cartilage Regeneration. Nanoscale, 9, 4430-4438. https://doi.org/10.1039/C7NR00352H

[181] Cosenza, S., Ruiz, M., Toupet, K., et al. (2017) Mesenchymal Stem Cells Derived Exosomes and Microparticles Protect Cartilage and Bone from Degradation in Osteoarthritis. Nature Scientific Reports, 7, Article No. 16214. https://doi.org/10.1038/s41598-017-15376-8

[182] East, J. and Alexander, T. (2020) IRB Approved Pilot Study of an Extracellular Ve- 
sicle Isolate Product Evaluating the Treatment of Osteoarthritis in Combat-Related Injuries. Stem Cell Research, 1, 1-10. https://doi.org/10.52793/JSCR.2020.1(2)-09

[183] Rajendran, R.L., Gangadaran, P., Bak, S.S., et al. (2017) Extracellular Vesicles Derived from MSCs Activates Dermal Papilla Cell in Vitro and Promotes Hair Follicle Conversion from Telogen to Anagen in Mice. Nature Scientific Report, 7, Article No. 15560. https://doi.org/10.1038/s41598-017-15505-3

[184] Sasaki, G.H. (2018) Hair Biology and Androgenetic Alopecia: Diagnosis, Neogenesis, and Management. Advances in Cosmetic Surgery, 1, 185-192. https://doi.org/10.1016/j.yacs.2018.02.014

[185] Sasaki, G.H. (2019) Review of Human Hair Follicle Biology: Dynamics of Niches and Stem Cell Regulation for Possible Therapeutic Hair Stimulation for Plastic Surgeons. Aesthetic Plastic Surgery, 43, 253-266.

https://doi.org/10.1007/s00266-018-1248-1

[186] Sasaki, G.H. (2021) The Effects of Lower versus Higher Cell Number of Platelet-Rich Plasma (PRP) in Hair Density and Diameter in Androgenetic Alopecia (AGA): A Randomized, Double-Blinded, Placebo, Parallel-Group Half-Scalp IRB-Approved Study. Aesthetic Surgery Journal, sjab23. https://doi.org/10.1093/asj/sjab236

[187] Liao, C., Booker, R.C., Morrison, S.J., et al. (2017) Identification of Hair Shaft Progenitors That Create a Niche for Hair Pigmentation. Genes \& Development, 31, 744-756. https://doi.org/10.1101/gad.298703.117 